\title{
Language in Politics \\ Features of the Soviet Language Policy in 1920s-1930s
}

\author{
Nubar Gurbanova, Universitas Airlangga \\ Rungthum Rangsikul, Universitas Airlangga
}

\begin{abstract}
Political language is a necessary tool of politics and power, which not only reflects reality, but also shapes it through information impact. Any multinational and multilingual state inevitably encounters the problem of regulating the linguistic life of the country. After the formation of the Soviet Union (1922), one of the important missions among national political tasks was occupied by the duty of setting up of national language. The national question was a very important problem in the first socialist state, since the Soviet Union was a multiethnic country. The differences in the territorial and natural conditions of the Caucasus, Central Asia, the Baltic, Siberia and the different historical destinies of the population of these territories presented great difficulties for the development of a unified plan for the progress of the culture of these nations and nationalities. The analytical article examines the main trends and features of the national language policy of the Soviet Union in the 1920s-1930s. A conclusion is made about the priority development of the Russian language, its role in the formation and shaping of the Soviet people as a qualitatively new historical community. The specifics of the interaction of the Russian language and the languages of the peoples of the Soviet Union in the pre-war period were analyzed.
\end{abstract}

Keywords: language policy; language prestige; Soviet Union; state language; russification

\section{Introduction}

Language and politics are two aspects that can be correlated as follows: language can be an instrument of policy, and can also be viewed as an object of politics. In the first case, we are talking about the conduct of politics by means of the language: language acts as an instrument of influencing society to achieve certain political goals, in this sense they speak of "language manipulation".

Language policies aimed at preserving or changing the status of a language always involve simultaneous exposure to other languages operating in the same state or international arena, since changing the status of one language entails a simultaneous change in status and other languages. Therefore, the status language policy is always complex: it involves the impact on specific languages as well as on a group of languages, both on the language situation in general, and on the communicative behavior of members of the language community.

Subjects of language policy under ordinary conditions are identical to the subjects of state policy: as a subject of politics, in both cases state power acts in forms specific for the country (monarchy or republic, democracy or autocracy, etc.). To the exclusive jurisdiction of the state is the language legislation. Language policy is an important component of national policy in multinational states and, as a result, becomes a system-forming factor that determines the constitution of the state, and consequently, the state power (Kuznetsov, 2007).

In one of the first political documents of the Soviet government - the "Declaration of the Rights of the Peoples of Russia" dated November 15, 1917 - the basic principle of the national policy of the Bolsheviks -the equality of all nations, understood, inter alia, as the right to use their native language regardless of nationality (Solchanyk, 1982). A number of legislative acts of 1918-1919 claimed the possibility of using local languages in court and at school (Martin, 2001). The decision of The 10th Congress of the Russian Communist Party (Bolsheviks, 1921) adopted a resolution determining the main course of the national language policy: "to help the 
working masses of non-Russian peoples to catch up with the central Russia that has left ahead" (Smith, 1998).

There were number of objective reasons for the Russian language to become more widespread on the territory of the Soviet Union: the centralization of government required a choice in favor of one of the languages that was to serve as a means of interethnic communication in a multinational country; a single language was necessary for the successful development of the science (Grenoble, 2003). A single language was required for the successful management of the army and navy. All this created the prerequisites for raising the role of the Russian language in Soviet society.

This research's main category is the historiographies and sociolinguistic analyses of language policies of the Soviet Union. The subject of the study is the comparison of the language situation and language policy in the Soviet Union in the 1920s-1930s, which, as is known, were a period of intensive language construction.

The existing periodization of language policy in the 1920s-1930s has several stages. The first stage, which took place until the end of the 1920s, is characterized by a pluralism of approaches, the desire to realize the existing needs and resources of peoples, to develop the literary languages of large nations. The second stage, which began simultaneously with the first five-year plan, was associated with the development of the processes of language construction and was characterized by the centralization of measures of language planning and the creation of active literary forms of language for illiterate peoples, as well as the transition to the Latin alphabet-all this was to contribute to the development of a socialist society. In 1934, the third period of language policy in the Soviet Union, was characterized by the spread of the Russian language among the nationalities, the translation of the national languages into a Cyrillic basis, and a general increase in the influence of the Russian language both on vocabulary and terminology and in the field of social functioning.

\section{Discussion}

\subsection{Language policy during the 1920s (from Pluralist to Assimilations policy)}

The first half of the 1920s is connected with the practice of independent language regulation in national territories. At the 12th Congress of the Party in 1923, the foundations of the Korenizatsiya (indigenization) policy were approved, defining idea of which was to overcome the national prejudices of the peoples of the Soviet Union on the basis of proletarian internationalism (Ilishev, 2000). Practically it was embodied in formalizing the languages of "titular" nations in the development of written and literary language, in the introduction of primary education in their native language. It is curious that the idea of a territorial principle in national self-determination - the nation has the right to national self-determination only on its own territory, expressed by Stalin in the work "Marxism and the National Question" (1913), in fact did not find its use: national areas were created. At the same time, the question of the essence of the "nation" was essential: there were several obligatory attributes that it should have: such as a common language, a common territory, a common history and a common national character. For instance, before the 1930s, Karelians were considered a nationality (Austin, 1992), they became a 'nation' only as a result of socialist development, as defined by the Great Soviet Encyclopedia in 1953.

The main difficulty that was discovered shortly after the declaration of the Korenization policy was the complete absence or weak level of knowledge of the literary forms of the languages of the peoples of the Soviet states. According to the 1926 census, the literacy of the population was $25.2 \%$ in Azerbaijan, 22.8\% in Kazakhstan, $15.1 \%$ in Kyrgyzstan, $12.5 \%$ in Turkmenistan, $10.6 \%$ in Uzbekistan, $3.7 \%$ in Tajikistan (Altapov, 2000).

In 1921, the development of the Latin alphabet for the Ingush, Ossetians, Kabardians and for the Azerbaijanis was began. In 1923, the First Conference on the Education of the Peoples of the North Caucasus was convened, which approved an agreed draft of Latin alphabets for the Ingush, Ossetians, Kabardians and Karachais. The successes of Azerbaijan were highly appreciated at the 12th Congress of the Party. From the 1923-1924, the work on the 
use of the Latin alphabet in other Turkic-Tatar peoples with an underdeveloped national writing system (Kazakhs, Kazan Tatars, Bashkirs, Uzbeks, etc.) was organized (Dickens, 1988). The Second Conference on the Education of the Peoples of the North Caucasus in 1925 finally consolidated Latinization among the Ingush, Ossetians, Kabardians, Karachais and made a decision on Romanization among Chechens and Adygeans.

Differences in the pace of development of their own written language among different peoples, the diversity of ethnic groups and the vagueness of the boundaries between them required the centralization of activities on language development. In February-March 1926, on the basis of previously established All-Union Central Committee convened a new alphabet in I Turkic Congress in Baku, where the representatives of the Eastern Republics were encouraged to take into account the successful experience of Romanization in Azerbaijan (Nurmakov, 1934). For the first time, the slogan of unification of the alphabets - an interethnic graphic and phonetic association of national Latin alphabets is put forward. Unification should meet the tasks of cultural and political unification of peoples while preserving the possibility of independent language development and its expression in the alphabet.

The choice of the Latin alphabet as a single system of a new letter was due to ideological and social reasons, rather than linguistic, namely correspondence as an installation for the Europeanization of the peoples of Central Asia, the idea of a world revolution and the future of a single proletarian language were relevant in 1920s. In addition, the Latin script, in contrast to the Cyrillic and Arabic, was free from political associations with the past of these peoples.

\subsection{Language policy during the 1930s}

Since the mid-1930s, the new Latin scripts began to be replaced by Cyrillic alphabets (Grande, 1934). An important role was played by the decision adopted in 1938 by the Central Committee of the Party and the Council of People's Commissars (Government) "On the compulsory study of the Russian language in schools of national republics and regions". The following year, a special resolution was adopted on compulsory education in the army for this language of soldiers of non-Russian nationalities. The need for this measure on the eve of war was clear.

Of course, the Russian language was necessary for everyone who aspired to at least a minimum of social mobility. However, after the adoption of the decision in 1938, a large number of schools were closed with instruction in small languages, and when translating languages into Cyrillic, at least 12 peoples lost their written language in their own language (Winner, 1952).

By 1930, the Romanization and unification of the letters of peoples who had previously used the Arabic alphabet was being completed; now the priority direction is the creation of a letter for non-literate peoples and the translation into the Latin alphabet of the literary language of peoples with Syrian, Mongolian, Chinese scripts (Musayev, 1965). The active continuation of korenizatsiya gave its results. Data on the growth of literacy in the Soviet Eastern Republics were very indicative. In 1932, out of 12.4 million people in Uzbekistan, Kazakhstan, Azerbaijan, Tajikistan, Tatarstan and Turkmenistan, 5.8 million people were literate (McLeish, 1972).

At the 16th Congress of the Party, Stalin announcing the achievement by the Soviet society in the stage of socialism, approved a new formula for the "construction" of national cultures: "In fact, the period of the dictatorship of the proletariat and the construction of socialism in the USSR is the period of the flowering of national cultures, socialist in content, national in form". Demanding the continuation of the policy of Korenization, he singled out two dangers that arose in the context of the aggravation of the class struggle: "Great Russian chauvinism" (Kaganovich, 1931), reflecting the desire of the classes leaving the political arena to regain their former power, and 'local nationalism' expressed in the desired isolation of the bourgeoisie. Internationalism, formed by the development of national cultures, was to become the basis of the future of a single monolingual socialist society. 
In the period of industrialization in 1928-1931s, the status of "lingua franca" of the Russian language begins to be formalized (Crisp, 1990). In the context of the development of population migration and the exclusion of isolation in the collective by ethnicity, the Russians could learn everywhere in their native language, unfortunately national migrants were, national schools did not open. The development of the planned economy and the strengthening of the centralization of power at first were paradoxically combined with the struggle against 'local nationalism' and the non-observance of the still valid principle of "internationalism".

However, in the second half of the 1930s, a new concept of the Great Russian people, the "first among equals", and the "older brother" in the family of the Soviet peoples, more appropriate to the political situation of that time was being formed. The perception of the Russian as a more prestigious language and the lack of motivation to learn and use the native language showed itself against the backdrop of the achievements of the "kultshturma" (culture storm) in the turn of the 1920s-1930s along with other difficulties associated with administrative 'excesses' (Hirsch, 2000), a lack of national personnel, educational literature, funding. Therefore, in many respects the transition from the Latin to the Cyrillic in 1937-1940 did not cause rejection and was accepted calmly.

The adoption of a new constitution declaring the right of Soviet citizens to study in schools in their native language, on the one hand, and the proclamation of a single socialist society, on the other, also inconsistently embodied in reality. The elimination of national districts and rural councils, the redistribution of their borders, so that the Russian population residing on their territories was dominant, the abolition of national schools occurred simultaneously with the printed criticism of manifestations of "great-power chauvinism".

In March 13th, in 1938, Russian became a compulsory subject in all schools of the Soviet Union, as well as the only language of the Red Army, in which national formations were liquidated. The centralized leadership of the system of introducing and teaching the Russian language in the school begins, and Russian becomes the center where the socialist, Soviet terms, the expressions of socialist, Soviet ideas and feelings are radiated and disseminated, not only in the entire range of fraternal languages and peoples of our multilingual state, but also in all the languages of the world.

\section{Conclusion}

The Russian language played an integrating role in the emergence and development of a new historical community, while simultaneously giving this phenomenon an obvious ethnic characteristic and acting as the main sign of the emerging Soviet super ethnos. The basis of Soviet identity objectively was the Russian language - the language of interethnic communication, allowing representatives of various ethnic groups to feel their identity, similarity, closeness, involvement in a particular culture and spirituality.

Having considered two variants of the interaction of language and politics, one can come to the conclusion that language and politics are in deep interdependence. Due to specially selected linguistic means, a linguistic influence is carried by contributing to the realization of political goals and attitudes. Politics, in turn, determines the direction of language development, its position in the state. Thus, language is inseparable from politics and power relations. But we must not forget that the state policy, like the state itself, largely depends on the language that connects the population into a single nation, forms thinking, and a cultural gene pool.

\section{References}

Alpatov, V. M. 2000. 150 Languages and Policy 1917-2000: Sociolinguistic problems of the ussr and the post-soviet area (2nd ed). Moscow: Kraft. 91

Austin, P. M. 1992. Soviet karelian: the language that failed. Slavic Review, 51(1), 16-35.

Blank, S. 1988. The origins of Soviet language policy, 1917-1921. Russian History, 15(1), 7192.

Crisp S. 1990. Soviet language planning since 1917-1953. Language Planning in the Soviet Union. New York, p. 23-45. 
Department of General and Comparative Historical Linguistics of Lomonosov Moscow State University. Available at http://genhis.philol.msu.ru/printer_195.html. (Accessed on May 5, 2018).

Dickens, M. 1988. Soviet language policy in central Asia.

Grande, B. 1934. Unification of the alphabets in the alphabet of October. Moscow: Leningrad. p. $14-27$.

Grenoble, L. 2003. Language policy in the Soviet Union. Dordrecht: Kluwer Academic. p. 8286.

Hirsch, F. 2000. "Toward an empire of nations: border-making and the formation of soviet national identities." Russian Review. 59(2): 201-226.

Ilishev, I. G. 2000. Language and politics in multinational societies: Problems of theory and practice. Ufa: Kitap. p. 279.

Kaganovich, S. K. 1931. Struggle against great-power chauvinism and local nationalism in the field of linguistics. Literature and Art. 4, 88-95.

Martin, T. D. 2001. The affirmative action empire: nations and nationalism in the Soviet Union, 1923-1939. Cornell University Press. p. 75-124.

McLeish, J. 1972. The Soviet Conquest of Illiteracy. The Alberta Journal of Educational Research 18, 307-326.

Musayev, K. M. 1965. Alphabets of the Soviet peoples. Moscow.

Nurmakov, N. 1934. Latinization of the alphabet, wielding the proletarian revolution. In the Alphabet of October. Moscow: Leningrad. p.3-8.

Smith, M. 1998. Language and power in the creation of the USSR, 1917-1953. Berlin/New York: Mouton De Gruyter.

Solchanyk, R. 1982. Language and education in soviet schools. International Journal of the Sociology of Language, 33, 113-118.

Stalin, J. 1913. Marxism and the national question. Prosveshcheniye, 3(5), 300-381.

Stalin, J. 1951. Marxism and linguistics. New York: International Publishers.

Winner, T. G. 1952. Problems of Alphabetic reform among the Turkic peoples of soviet central Asia. The Slavonic and East European Review, 76, p. 133-147. 